\title{
Até tu, Pet, ou Rita no Pomar e a arte de (des)pentear cachorros
}

Ravel Giordano Paz

\section{Introdução}

Rinaldo de Fernandes não é propriamente um escritor conhecido do grande público. Embora textos seus já tenham merecido a atenção de leitores como Silviano Santiago, Moacyr Scliar, Mário Chamie e José Castello - para citar as quatro primeiras assinaturas de comentários na contracapa de Rita no pomar -, o autor mesmo reconhece que sua atividade literária mais conhecida é a de organizador de coletâneas ${ }^{1}$. É verdade que a obra de Fernandes avulta ainda modesta num mercado cada vez maior e mais inflado: ao título referido, seu romance de estreia, somam-se apenas dois volumes de contos ${ }^{2}$, além dos publicados esparsamente; o próprio Rita no Pomar, em termos de dimensões - 96 páginas, incluindo as em branco que separam capítulos, sendo alguns destes brevíssimos (um deles com apenas uma linha) -, se aproxima mais de uma novela. Mas justamente a síntese cuidadosa, sempre atenta às necessidades do enredo bem pensado e urdido, e o trato minucioso da palavra, precisa no captar dos acentos sociais e psicológicos, são qualidades que recomendam a literatura de Fernandes, e participam dos elementos que fazem da história de Rita muito mais do que um caso típico ou sintomático de psicose e violência urbana ${ }^{3}$. Como notou e sublinhou Silviano Santiago (2008, p. 103) em seu posfácio ao romance, Fernandes evita "encardir a narrativa com sangue. Opta pelas reticências, que prendem o fôlego do leitor, ao lhe liberar a imaginação para as conjeturas de sentido e o refazimento da narrativa". Daí o singelo título de seu texto, "A arte do penteado", com o qual o ensaísta criou uma metáfora para a condição do escritor contemporâneo, que já não poderia compor "uma história por inteiro", mas apenas lidar com "mil e um fios narrativos, dispersos e soltos no cotidiano, que não são mais passíveis de ordenação ou pelo cabo ou pelo rabo" (SANTIAGO, 2008, p. 97-98). Sem dúvida, isso diz muito de essencial sobre Rita no pomar; e se ainda assim nos parece proveitoso retomar esse livro é porque em um bom penteado é sempre possível surpreender - ou compor - novos arranjos, ou ainda atentar para um ou outro fio astuciosamente solto, e mesmo, quem sabe, avistar alguns pelos (desses que perderam o acento ${ }^{4}$ ), caninos ou nem tanto, escondidos bem ali, onde os fios de um risco se embaraçam. Ainda mais estando, esse penteado, em mãos que nunca se sabe ao certo qual tipo de pente empunharão - e menos ainda como deixarão a cabeça do freguês após o serviço.

Em linhas gerais - as quais, cumpre alertar, serão aqui amplamente expostas -, a história de Rita é de uma simplicidade notável, quase tanto quanto o grotesco de seus acontecimentos principais. Na verdade, não deixa de participar dessa simplicidade certa linearidade estrutural, na medida em que a narrativa comporta, sim, uma espécie de arremate - ou quase isso, já que as revelações da última página não constituem exatamente um fecho para a saga de sua pequena e sinistra anti-heroína. A linha que constitui o 
último parágrafo, e que de fato se institui como um fecho narrativo - quase um fecho de ouro: mal se resiste à tentação de escandi-lo: "E não late, que eu também te mato!" (FERNANDES, 2008, p. 96) - é também uma abertura, no mínimo para um possível cumprimento da ameaça; o que não é propriamente uma banalidade, na medida em que, para além de seu efeito anedótico de superfície, essas palavras também coroam a relação enunciativa em cuja esfera (embora não apenas nela, pois há também a das escritas da protagonista) Rita no Pomar se torna uma narrativa bem mais rica e profunda do que seria um relato meramente "ocorrencial". Se há aqui uma discordância em relação à leitura de Santiago que nos parece necessário assinalar é esta, ou seja, a que diz respeito ao lugar, na narrativa, desse pet - ou melhor, esse Pet em "pessoa" -, esse receptáculo quase passivo dos "cuidados" e de boa parte do que nos é dado da história de Rita. Isso que Santiago (2008, p. 101-102) define como um "um mero e indispensável acessório teatral (um prop, como se diz em inglês)" nos parece o elemento fulcral de uma estratégia sêmico-composicional de grande importância: é por meio dele que nos afigura vazar, por entre os fios e as reticências, a riqueza formal, psicológica e antropossociológica de Rita no Pomar, configurando sua narrativa como uma arte, "penteado" que seja, tão sutil quanto profundamente ambígua e inquietante. Um elemento, no entanto, que determina, também, e sem dúvida que paradoxalmente, o em si mesmo ambíguo sopro libertário - quando menos, de esperança - que porventura advém desse livro: um sopro (ou "assopro", dir-se-ia para volúpia ou desespero de Rita), pode-se dizer, tanto dissimulada quanto genuinamente canino, ou, em termos semelhantes, simultaneamente cínico e kyniko.

\section{Pet e o pente}

Voltemos, no entanto, às anunciadas linhas gerais, ou seja, as constituídas pelo conjunto de relatos e "confidências" que Rita faz ao cachorro, ou registra no diário e, ainda, na forma de textos que ela mesma chama de contos. Essas diferentes ruminações discursivas dizem respeito, sobretudo, à pequena mas complexa teia de relações da personagem, tanto as passadas, referentes principalmente aos dois casamentos já acabados - um ainda em São Paulo, com o ex-ladrão André, e o outro já na semideserta Praia do Pomar, na província paraibana onde ela se refugiara, com o pescador Pedro - e às figuras que gravitam no entorno espaço-temporal desses consórcios: no primeiro caso, a mãe de Rita, Lúcia, a empregada Telma e o cachorro Rex; no segundo, além de Pet, alguns aparentes meros figurantes: Rui, dono do restaurante onde Rita se empregara, o filho dele, Márcio, o garçom Rômulo e seu filho, não nomeado. Os acontecimentos surgem de forma elíptica e fragmentária, e seria muito dispendioso listá-los e ordená-los aqui: ao invés disso, nos reportaremos a eles ao longo de nossa análise. Registre-se, por enquanto, que em ambos os núcleos espaço-temporais têm lugar ("efetivamente" ou não) um par de eventos decisivos, justamente os narrados nas últimas páginas: a traição de Rita pelos maridos - o primeiro com a mãe dela e o segundo com o filho de Rômulo - e o assassinato, por ela, dos casais (supostamente) adúlteros. 
É essa revelação que imprime um selo decisivo ao caráter de Rita: o selo, evidentemente, de uma loucura ou algo próximo disso. Mas também é evidente que, por mais impactantes que sejam esses eventos, eles não resumem o que há de importante no livro. E não é preciso apelar para a familiaridade de Fernandes com a obra de Machado de Assis ${ }^{5}$ para perceber o quanto o jogo de luzes e sombras de Rita no Pomar, com sua narrativa acusatória a cargo de uma parte envolvida e não necessariamente confiável, remete aos de Dom Casmurro: basta que a mera possibilidade nos ocorra para que ela se torne factível, embora essa lembrança possa ser dificultada pelas diferenças estilísticas e estruturais dos dois romances, além, obviamente, da violência mais explícita do de Fernandes. Ao mesmo tempo, justamente esse último dado, se por um lado explicita a pouca confiabilidade de Rita, de certa forma também lança um claro-escuro sobre suas consequências, como se qualquer desconfiança de nossa parte se tornasse menor diante de "fatos" - remetam as aspas somente ao pacto ficcional, já que na história de Rita eles parecem efetivos - que são, em todo caso, atrozes e, afinal, confessos. Daí o risco de subsumirmos tudo aos atos criminosos, fechando o livro com a satisfação pífia de quem diz aos botões que desconfiava de tudo (ou quase tudo, ou pelo menos de alguma coisa) desde o início. $\mathrm{Na}$ verdade, a própria insuficiência programada desse gozo detetivesco e do outro ao qual ele se liga - o de um exercício de imputação de uma culpa ou um desajuste psicológico - convida a ir além dele, ou melhor, àquilo que ficou para trás, e que a própria brevidade do texto talvez sugira revisitar.

É só numa segunda leitura ou depois de alguma ruminação interior ${ }^{6}$ que a complexidade da construção de Rita e as dimensões do inferno interior em que ela vive, e exterioriza impingindo-o aos outros, menos ou mais inocentes, começam a emergir com clareza, simplesmente porque é só ao final do texto que se completa o "estalo", que permanece o tempo todo fantasmalmente suspenso sobre nossas cabeças, de que o que se passa ali é muito sério, e só então a espécie de expressividade trágica que viceja à flor da pele da narrativa é irremediavelmente ativada. Só depois de conhecer Rita "por inteiro" é que sabemos como pisar nos delicados ovos de suas palavras e mover-nos no esquivo universo enunciativo-psicológico de sua autocomplacência - sabemos, afinal - monstruosa. E somente aí percebemos inteiramente as dimensões, para além da história que se desvelou, dos dramas em curso, ou seja, esses que permanecem inconclusos: o da convivência com Pet e as demais relações "atuais" da protagonista, inclusive consigo mesma, e não só com o passado como com o fantasma presente-ausente do que se é então. Qual, afinal, a razão da dificuldade de os horrores passados virem à tona verbalmente, diante do bicho ou de um caderno, senão o horror que Rita se tornou aos seus próprios olhos, e que, mesmo não se ocultando no inconsciente - pelo contrário, sempre enormemente presente em sua ausência enunciativa, e aqui e ali ameaçando emergir, como um tabu ameaçadoramente ostentado diante de Pet -, ela hesita sempre em encarar? Ou admitimos a gravidade desse "caso" ou atribuímos a toda a discursividade que antecede as revelações a mera função de criar suspense. E o fato é que, relidas sob o prisma do que se revelou, diversas passagens de Rita no Pomar atestam que é da primeira situação que se trata; e nisso, nesse desvelamento de uma condição patológica extrema, convém sublinhar, é a riqueza e sutileza de uma construção artística, e não a pobreza de um mero naturalismo, que se delineia. 
Para além de uma função estrutural, a relação com Pet ao mesmo tempo disfarça e explicita um dado fundamental na psicologia da protagonista e portanto da construção do enredo, inclusive em suas dimensões simbólicas: Rita é, sem muito exagero, o interdito em pessoa. Suas broncas no cachorro, embora não se desdobrem em atos de violência física, praticamente equivalem à proibição de qualquer contato, num rito permanente de atração e rejeição marcado por acentos acusatórios e punitivos, tão mais cruéis e absurdos porquanto aplicados a um ser inocente, e não raro incidindo sobre sua fragilidade e desamparo: é como uma forma de acusação e cobrança, por exemplo, que Rita faz "notar" a Pet que seus pelos estão piorando, ou que o censura por um "hábito", o de balançar as patas, que talvez seja sintoma de uma doença fatal (a cinomose), embora nesse caso haja o atenuante - mas apenas isso, porque a repressão não deixa de existir - do provável desconhecimento clínico. A tal ponto, em todo caso, tudo isso é recorrente, que é difícil não imaginar a vida de Pet como um constante estado de angústia, do qual as pessoas acostumadas à convivência com os cães sabem que eles, sobretudo os "carentes", como é o caso, são perfeitamente capazes. Os frequentes "choros" do cachorro, que inicialmente podemos ver como algo "gracioso", deixam-se entrever aos poucos, ou numa segunda leitura, como possíveis reações a uma relação fundada numa instrumentalização afetiva de mão única: Rita não apenas exige ser somente ouvida, negando a necessidade de aproximação física que sua própria voz desperta no bicho, como exige dele atenção integral, queixando-se até de seu sono. Na verdade, a ameaça que se verbaliza no final paira a todo instante sobre ele, inclusive pela sempre adiada - e afinal nunca realizada - revelação a respeito do que houve com o antecessor Rex, do qual só sabemos que está morto. No entanto, justamente esse "suspense", cuja condição de possibilidade é a perturbação de Rita, de certa forma a disfarça, na medida em que, conforme uma velha anedota (a do patrão que agride o empregado, que desconta na esposa, que desconta no filho, que desconta no cachorro), o animal doméstico ocupa os últimos (ou primeiros) lugares na escala dos ritos catárticos cotidianos. Além disso, a própria intriga com seus mecanismos, nos quais Pet cumpre, de fato, uma função instrumental (que é, portanto, dupla: nas mãos do escritor e da protagonista), tendem a minimizar o terror quase permanente de sua tortura emocional.

E é nisso, nessa sutil "normalização" da violência por um "objeto" em relação ao qual seu exercício comporta certa conivência de nossa parte - conivência esta reforçada por mais de um tipo de complacência reivindicada por Rita -, que consiste, a nosso ver, a grande maestria narracional de Fernandes. Uma maestria, no entanto, que presta-se menos a reforçar um impacto final - o escritor sabe, certamente, que em matéria de atrocidades é difícil competir com o noticiário - do que, justamente, a confrontar-nos com nossa complacência diante de uma atrocidade perene, e que não é apenas a que incide sobre Pet, ou sequer o monstro moral que se tornou Rita, ou mesmo a monstruosidade de tudo o que ali se fez e disse, mas da própria possibilidade/ "efetividade" disso tudo, ou seja, de um estado de vida que possibilita tudo isso. Que a relação com Pet de certa forma espelha ou alegoriza outras é algo sublinhado por um detalhe que o leitor atento dificilmente deixa de notar, mas que também pode passar por um mero jogo literário: o principal motivo das broncas de Rita é um "gesto" recorrente, a saber, os "assopros" do cachorro, que também surge (em meio, ainda, a unhadas e mordidas), na narração dos 
primeiros e estranhíssimos contatos, digamos, amorosos da protagonista com seus dois maridos. O primeiro episódio é recriado no conto intitulado "A invenção de André", "personagem" este do qual a narradora-protagonista diz que "veio assoprando" sobre ela (FERNANDES, 2008, p. 51). Na narração a Pet da aproximação íntima com Pedro, Rita diz, em substituição a esse mesmo verbo (dizer), que "ele assoprou, vamos andando pro barco"; depois, é a protagonista quem, interrompendo as carícias que ela mesma iniciara, serve-se do mesmo verbo e da mesma esquiva: "assoprei, o barco" (FERNANDES, 2008, p. 74). É nesse movimento de atração e rejeição, que informa insistentemente os afetos de Rita, que se instaura o vínculo mais forte entre as relações. Diversos episódios do livro podem ser vistos à sua luz - por exemplo o da suposta tentativa de sedução pelo dono do hotel onde Rita se empregara, seu Rui, com seus "pêlos brancos no peito" (FERNANDES, 2008, p. 59), e que depois parte em uma misteriosa viagem, assim como na relação com o filho dele, o odiado e provavelmente amado Márcio, que ela descreve "sem camisa, o peito parecendo o do pai" (FERNANDES, 2008, p. 67) -, deixando entrever um complexo psicológico relacionado à ausência paterna (que comentaremos mais adiante) e que talvez ganhe um tipo de simbolização no fantasma do velho do Pomar.

Entre os fios que escolheu a dedo para seu próprio enredo, ou seja, a pequena teia comparativa que compõe em torno de Rita no Pomar, Silviano Santiago incluiu duas obras fílmicas: Kill Bill e El mariachi, respectivamente de Quentim Tarantino e Robert Rodríguez. Outra que renderia aproximações interessantes com a história de Rita é o "clássico" - inclusive na formação dos diretores citados - Psicose, de Alfred Hitchcok ${ }^{7}$, e não apenas pelo tema como por certo "expressivismo" e mesmo pela situação enunciativa de certa forma semelhante das duas histórias, ambas com um enunciador dirigindo-se frequentemente a uma espécie de enunciatário fantasma. Aquilo, porém, que na figura de Norman Bates literalmente salta aos olhos, aqui exige atenção redobrada: quando, por exemplo, Rita, no início de suas "confissões", diz que a mãe tinha "as pernas perfeitas, ô, mas não fui feita pra ser traída" (FERNANDES, 2008, p. 96) -, é só na medida em que pressentimos o que se segue que visualizamos o arregalo, devidamente ensombrado pela loucura, desse "Ô" nos olhos da personagem. Evidentemente, a ausência de um narrador onisciente que assumisse o lugar da câmera cinematográfica é um dado determinante na sutileza desse expressivismo no fim das contas tão dramático, a cargo, nas palavras de Santiago (2008, p. 102), de uma "voz única ao telefone do desespero narrativo". Mas é no jogo enunciativo-imolatório que encobre e descobre sua loucura que a Rita enunciadora deixa vazar, por entre os dentes, a espessura desse desespero, a raiva espessa mas tão líquida que não é de se estranhar que contamine seu enunciatário não tão ausente assim ("Não late..."). É esse jogo que desconstrói o suspense hitchcockiano, porque faz emergir, sob a intriga do primeiro plano, o drama profundo do embate das alteridades.

Com o derradeiro desvelamento da expressividade dramática de Rita, é também uma transparência de alma - e nisso, evidentemente, reside o paralelismo profundo com Pet -, com suas demandas urgentes e desamparadas, que se revela; o que também obriga a desentranhar como tais, ou seja, como almas-demandas ${ }^{8}$, as figuras que habitam fantasmalmente sua narrativa. E nisso, para além de qualquer patologia e mesmo complexidade individual, é todo um conjunto de relações - ou a totalidade das relações 
sociais (ainda que configuradas numa totalidade aberta), nos termos lukacsianos que afinal talvez não desabonem o romance de Fernandes - que se mostra em uma mesquinhez que incide até mesmo sobre o contato com aquilo que se sente como dotado da natureza mais pueril e inofensiva, e que a própria natureza interior convida a acolher. Sem dúvida que há um tanto de ofensa à mentalidade misógina no fato de alguém "destinado" a ser uma "fonte" ou "guardiã" da vida se tornar sujeito não só de seu discurso como de ações vis - ainda mais esta específica, a vingança conjugal - outrora concebidas como "privilégio" do "sexo forte". Mas evidentemente, ao contrário do que se dá no primeiro caso, essa democratização das posições punitivas não tem o que mereça ser celebrado, ainda mais quando atesta que o território onde se opera ainda é o mesmo, de relações de poder estratificadas, volatilizadas - se é que o são - apenas pelos jogos e ritos sinistros, fadados a assumir uma feição congestiva, autofágica. Não por acaso é nas disputas com a mãe, que giram em torno não só de André, mas também da atividade literária e, óbvia mas muito sutilmente, do pai de Rita - invocado apenas uma vez, justamente pela figuração "ficcional" da mãe - que se condensa a mesma competitividade arraigada e doentia que enforma as relações "atuais" da protagonista.

Quanto mais, porém, os discursos de Rita se configuram de forma (sutilmente ou não) maniqueísta e raivosa, mais eles fazem sangrar os fantasmas, vivos ou mortos, que invocam, na mesma proporção em que deixam vazar o sangue por entre os dentes dessa (anti)Homero ou (anti)Ulisses literalmente sui generis (embora também, naturalmente, uma anti-Penélope). No gesto não menos sutilmente revoltado desse antimaniqueísmo radical, mas sem concessões sentimentais, o romance de Fernandes pode ser visto como um questionamento não menos radical do sistema da culpabilidade jurídico-psicológica que fundamenta narrativas como Psicose e outras muito mais reais. É claro que também é possível imputar a Rita uma mera culpabilidade (e/ou patologicidade); nesse caso, porém, estaríamos negando qualquer valor a tudo o que ela nos conta do mundo, e a própria personagem subexistiria como uma aberração metafísica, que extrai do nada o horror do que é e do que conta. Mas, afinal, talvez também seja num território jurídico que a radicalidade artística de Fernandes - semelhantemente à de cineastas como Lars von Trier e Gus Van Sant - se e nos situe: cabe a nós aceitar ou não as evidências do estado do mundo com que ela nos defronta. E tão mais radical é esse gesto, talvez, porquanto é a um outro, contra nós mesmos, ou seja, contra nosso algum grau de anestesiamento e complacência, que ele nos convida: quando menos porque é sempre a partir de nós mesmos que vemos o mundo.

\section{Da (semi)forma(ção) cínica à (de)forma(cão) kynica}

Pouco importa, portanto, se a narrativa de Rita é inteiramente "factual" ou não. A rigor, e o noticiário o atesta plenamente, ela é perfeitamente verossímil, incluindo o conteúdo de seus ritos acusatórios, mas seu valor - digamos, "humano" - reside antes de tudo na mera possibilidade de que um coração-e-mente possa conceber o mundo como um tal inferno de relações amesquinhadas, e que não pode ser inteiramente alheia ao próprio mundo. Em outros termos, é no âmbito do próprio discurso que se verificam as fraturas: do discurso como rastro doloroso do mundo. Não por acaso, a premência 
discursiva de Rita se reparte em diferentes registros, menos ou mais presos às agruras do passado mas nunca inteiramente livres delas. Um caso importante, naturalmente, é o dos textos que, merecendo ou não esse nome, Rita apresenta como contos. Em um deles (FERNANDES, 2008, p. 79-80), "A senhora do edifício", pode-se entrever a aspiração de uma conciliação plena das relações - com os pais, a libido, a natureza, a linguagem e, finalmente, as de classe - em que se esgarça a vida de Rita, sublimadas, talvez inconscientemente, numa epifania na qual ela e a mãe parecem se fundir numa figura que se permite a volúpia desejante liberta de preconceitos - e, no caso de Rita, com prováveis acentos edipianos (ou "electrianos") - por um mendigo. Mas esse tipo de recriação de certa forma elevada - porquanto libertária, ou, talvez mais propriamente, liberta - da "vida real"" nem sempre se reconhece em outros contos.

Pelo contrário, sobretudo nos primeiros que lemos é um "biografismo" por vezes algo torpe - a despeito das efetivas qualidades literárias - o que predomina, como já se entrevê no título do primeiro (FERNANDES, 2008, p. 37): "Café da manhã de minha mãe com Telma". O segundo retoma essa "personagem", Telma, para explorar um acontecimento mencionado no anterior, e que lhe dava seu tônus dramático: a morte de seu filho em uma operação policial. Lido em seu trânsito de um conto ao outro, e ainda para um terceiro, esse episódio recorrente deixa entrever alguns dos mecanismos psicológicos que subjazem às pulsões artísticas de Rita. No primeiro, há a emergência, em meio à verborragia queixosa e afetada da mãe, da dor da empregada pela lembrança da tragédia ainda recente e do gesto hipócrita do policial, conforme ela saberia depois, responsável pelo tiro, consolando-a ou fingindo consolá-la. No segundo se dá a narração direta desse episódio; aqui, no entanto, nosso vínculo empático com Telma é volatilizado por um gesto ambíguo seu: o de segredar, por três vezes, algo no ouvido do filho moribundo, palavras que o policial - que agora permanece tenso, com a arma na mão - tenta inutilmente escutar (cf. FERNANDES, 2008, p. 45-46). Finalmente, esse drama retorna, mais discretamente, no último conto do livro, no qual um narrador masculino se dirige à esposa, como em uma carta, para lhe falar vagamente sobre "algo tão apaixonante" (FERNANDES, 2008, p. 83) que lhe fora dito pelo filho antes de morrer. Nesse jogo de continuidades e permutas, são as demandas da própria Rita - por vezes, talvez, à sua própria revelia - que dão as cartas. A solidariedade com a empregada, certamente em parte motivada pelos conflitos com a mãe, dá lugar ou pelo menos se confunde, no segundo conto, a uma perspectiva algo cruel e à primeira vista incompreensível, mas que se torna um pouco menos quando sabemos, no fim do livro, que a empregada, menos zelosa devido à perda recente, fora demitida por pressão de Rita, para facilitar a execução de seu plano sinistro: delineia-se aí uma possível transfiguração de uma consciência culpada em um rito acusatório capaz de aplacá-la. No terceiro conto, acrescenta-se outro dado importante, exposto no capítulo anterior, relacionado ao passado de Rita: seu plano fracassado de ter um filho com o primeiro marido. É essa pequena ausência comovida que permite não só uma visão quase beatífica do marido, dormindo "todo torto no colchão, a cabeça no travesseiro" (FERNANDES, 2008, p. 82), como, no conto que se segue a essa visão, uma espécie de pacificação, ainda que dolorosa, do tumulto interior que nasce disso tudo. 
Bem se vê que essa alma fraturada possui também um quê daquilo que no romantismo se denominava uma bela alma. $\mathrm{O}$ fato de Fernandes ter emprestado à personagem-contista seu próprio poder imagístico e de síntese, e mesmo sua sensibilidade humana e poética, certamente não é gratuito, mas participa da tentativa de concessão de uma sensibilidade "efetiva” a Rita, e também, portanto, da estratégia de constituição de nosso vínculo empático com ela. Não obstante, também aqui há uma armadilha, na medida em que o pendor artístico da personagem tende a encobrir a profundeza de seu rebaixamento existencial, que, lembre-se, incrusta-se diretamente em sua linguagem e na relação com o mundo e consigo mesma que se constitui por meio dela. Revista sob a hesitação de trazer à tona o horror dos assassinatos, a prática literária de Rita revela seu débito com a autocomplacência perene em suas falas e anotações no diário: a mesma que a faz acusar Pet de piorar o pelo, como se ele o fizesse para incomodá-la, ou soterrar sob pás de culpabilidade as pessoas que ela matara. De fato, uma espécie de petição de inocência - uma petção, dir-se-ia, não fosse a infâmia do trocadilho, que, no entanto, sublinha a tentativa da personagem de figurar como uma espécie de cão carente e sem dono - informa todos os campos discursivos de Rita. Numa passagem particularmente grotesca, ela se queixa, no diário, de que Márcio lhe dissera para não "estar de conversa com o Rômulo, o imbecil, eu querendo ajudar o Rômulo, ele ficou muito triste depois que o filho desapareceu..." (FERNANDES, 2008, p. 33). A quem quer que se refira "o imbecil” - a Márcio, como parece ser o caso, ou ao próprio Rômulo -, o fato é que tanto essa agressão verbal quanto o tom piedoso que se segue chocam-se violentamente com o que saberemos depois acerca do referido desaparecimento (ou seja, que Rita é a responsável por ele): eles atestam o acinte quase insuportável - quase idêntico, aliás, ao que o policial impinge a Telma (ou à sua figuração ficcional no conto) - de um cinismo extremo, o mesmo que subjaz a quase toda a discursividade de Rita. E é nesse ponto extremo que se percebe o quanto essa "bela alma" é também um caso, igualmente extremo, daquilo a que Adorno (1996) denominava a semiformação do indivíduo sob a égide da indústria cultural, não obstante Rita, com sua formação jornalística e seu gosto pelas páginas políticas e culturais dos grandes periódicos, pretenda ser também o que se chama uma formadora de opiniões. Vide, no entanto, a perfeita banalidade com que fala sobre o artigo que escreveu "pedindo a cassação dos vereadores por atos de i-m-p-r-o-b-i-d-a-d-e a-d-m-i-n-i-s-t-r-a-t-i-v-a" (FERNANDES, 2008, p. 91), gesto este, aliás, que - virtudes éticas à parte -, somado à atividade de revisora exercida em São Paulo (com um alegado zelo que, a julgar pelo dispensado a Pet, devia confinar com o de uma censora), ajuda a compreender o lugar de Rita na semicultura, da qual ela se revela não só um "produto" como um agente - ou seja, um agente repressivo -, inclusive no que atua sobre si mesma.

A quem, afinal, se dirige sua petição de inocência senão ao tribunal de sua consciência? Justamente isso, porém, nos exige conceder um paradoxal crédito a essa petição, enquanto fruto de uma alma doente que, mesmo submersa no horror que se tornou, ainda clama por uma inocência fundamental - a de cães e crianças - anterior a tudo isso; uma alma que de alguma forma, embora a mais improvável - ou seja, fechando os olhos e a boca - quer despir-se de seu próprio horror. É nessa demanda profunda e tragicamente irrealizável que o cinismo de Rita desliza para um sopro de liberdade, ou, que seja, um mero assopro, mas digno, quem sabe, de outro cinismo: o dos filósofos cínicos, que também poderíamos 
chamar, valendo-nos da raiz grega - a mesma, lembre-se, de "cão" -, de kynicos (ou, ainda, cânicos, mas este é um trocadilho ainda menos apetecível). Ou não é à liberdade e o despojamento de um Diógenes de Sínope, ou, mais ainda, à vida plena de um verdadeiro cão livre que ela aspira, com mais fôlego que o próprio Pet $^{10}$, em seus passeios noturnos pela praia, sem medo da "cólera" dos coqueiros? (Cf. FERNANDES, 2008, p. 55-56.) Fossem outros os tempos e os ares - pois, como notou um leitor "conterrâneo" do imaginário Pomar paraibano (cf. MOUSINHO, 2009), mais de uma forma de degradação já o rondava antes da chegada da paulistana -, fossem os tempos, dizíamos, se não menos ferozes quem sabe menos cínicos e mesquinhos, talvez essa Rita fosse uma versão humana, feminina e tropical de outro pet, ou melhor, um ex-pet: o Buck de Jack London (1974), que se liberta de todo jugo doméstico para espalhar filhos pela floresta ártica. A seus olhos, então, o mar nordestino não mais rosnaria "como um cão que, de repente, assustado, se descobriu verde” (FERNANDES, 2008, p. 79): sem ostentar o orgulho mítico daquele mar onde se banhava a Iracema alencariana (a mesma, no entanto, que deu o seio aos cães para que brotasse o leite ansiado por seu filho com o colonizador Martim), e tampouco a (a)feição pueril de um cão verde e sem rosto (o Floquinho de Maurício de Souza), e menos ainda a cólera ainda maior de outra fera verde, embora mais "humana" (o Hulk da Marvel Comics), talvez os verdes mares - não propriamente domesticados, mas desassombrados - dessa derradeira história de exílio espelhassem simplesmente a nostalgia (ou o enfado) desse adjetivo - "humano" - que o bicho homem raramente soube honrar.

Notas

${ }^{1}$ Como fez em depoimento na Feira do Livro de Brasília de 2008. As coletâneas organizadas por Fernandes incluem Contos cruéis: as narrativas mais violentas da literatura brasileira contemporânea (Geração Editorial, 2006) e Capitu mandou flores: contos para Machado de Assis nos cem anos de sua morte (Geração Editorial, 2008).

${ }^{2}$ O caçador (Edufpe, 1997) e O perfume de Roberta (Garamond, 2005).

${ }^{3}$ Do que, a nosso ver, se aproximam mais algumas narrativas de Fernando Bonassi.

${ }^{4}$ Os quais, no entanto, manteremos nas citações do romance de Fernandes.

${ }^{5}$ Cf., em todo caso, a já mencionada coletânea Capitu mandou flores (FERNANDES, 2008a).

${ }^{6}$ Ou então numa leitura abrupta, de um só fôlego, que se mantenha no fio das tensões e seja capaz de atualizá-las cada vez que novos dados, ou seja, novos fios, se lhes adicionam (apesar do "finalismo" que já comentamos, e mesmo da construção de certo "suspense", trata-se, vale ressaltar, de uma narrativa de grande fragmentariedade). Ou ainda, quem sabe, numa leitura em voz alta, que ao menos demande o respeito ao tom do que se enuncia. ${ }^{7}$ Mas há também o remake, talvez ainda mais psicótico - justamente porque adiciona um ingrediente de cinismo semelhante ao de Rita no Pomar-, de Gus Van Sant.

${ }^{8}$ Aproximamos aqui duas problemáticas distintas, ou talvez nem tanto: a da alma como categoria estética em Bakhtin (1992) e a do pensamento das demandas de Derrida (1994).

${ }^{9}$ Antes de escrever o conto, Rita sonhara ser uma senhora que desejava um mendigo que, por sua vez, era seu ex-marido André (cf. FERNANDES, 2008, p. 75). Embora nem aí nem no conto a mãe seja mencionada, isso não nos parece impedir a relação, ainda que num nível inconsciente - de Rita e, quem sabe, do próprio romancista. Sublinhe-se, aliás, que muitos elementos de nossa interpretação pressupõem menos a intencionalidade autoral do que a propriedade da práxis artística de captar e problematizar o real na dialética da intuição do artista com suas determinações históricas e estéticas.

${ }^{10}$ Lembre-se, aliás, o elogio do exercício físico por Diógenes. 


\section{Bibliografia}

ADORNO, T.-W. Teoria da semicultura. Trad. de Newton Ramos de Oliveira, Bruno Pucci e Cláudia B. M. de Abreu. Revista Educação e Sociedade, n. 56, dez. 1996, p. 388-411.

BAKHTIN, Mikhail. Estética da criação verbal. Trad. de Maria E. G. G. Pereira. São Paulo: Martins Fontes, 1992. DERRIDA, Jacques. Espectros de Marx. Trad. de Anamaria Skinner. Rio de Janeiro: Relume Dumará, 1994. FERNANDES, Rinaldo de. Rita no Pomar. Rio de Janeiro, 7Letras, 2008.

. (Org.) Capitu mandou flores. Contos para Machado de Assis nos cem anos de sua morte. São Paulo, Geração Editorial, 2008a.

LONDON, Jack. O apelo da selva. Trad. de Rui Guedes da Silva. São Paulo: Círculo do Livro, 1995.

MOUSINHO, Luiz Antonio. Na conta da dor do mundo: a feroz paisagem interiorizada de Rita no Pomar. In: http://www.7letras.com.br/detalhe_livro/?id=67. Acesso em 01 de abril de 2009.

SANTIAGO, Silviano. A arte do penteado. In: FERNANDES, Rinaldo de. Rita no Pomar. Rio de Janeiro, 7Letras, 2008. p. 97-103. 